\title{
Calibration and simulation of ASM2d at different temperatures in a phosphorous removal pilot plant.
}

\author{
F. García-Usach*, J. Ferrer*, A. Bouzas** and A. Seco** \\ * Dpto. Ingeniería Hidráulica y Medio Ambiente. Universidad Politécnica de Valencia. Camino de \\ Vera s/n. 46022. Valencia. Spain \\ (E-mail: magarus@hma.upv.es; jferrer@hma.upv.es) \\ ** Dpto. Ingeniería Química. Universidad de Valencia. Doctor Moliner 50. 46100. Burjassot. \\ Valencia. Spain \\ (E-mail: aurora.seco@uv.es; alberto.bouzas@uv.es)
}

\begin{abstract}
In this work an organic and nutrient removal pilot plant was used to study the temperature influence on phosphorous accumulating organisms. Three experiments were carried out at 13, 20 and $24.5^{\circ} \mathrm{C}$ achieving a high phosphorous removal percentage in all cases. ASM2d model was calibrated at 13 and $20^{\circ} \mathrm{C}$ and the Arrhenius equation constant was obtained for phosphorous removal processes showing that the temperature influences on the biological phosphorus removal sub-processes in a different degree. The $24.5^{\circ} \mathrm{C}$ experiment was simulated using the model parameters obtained by means of the Arrhenius equation. The simulation results for the three experiments showed a good correspondence with the experimental data demonstrating that the model and the calibrated parameters were able to predict the pilot plant behaviour.
\end{abstract}

Keywords

Activated sludge plants; ASM2d; biological nutrient removal; calibration; temperature.

\section{INTRODUCTION}

The number of wastewater treatment plants (WWTPs) equipped with biological nutrient removal is increasing worldwide. Several studies have been carried out to establish the influence of the main parameters affecting the biological phosphorus removal (BPR). The sludge retention time (SRT) variation has an important influence on the BPR. It has been stated that the SRT affects the phosphorus-glycogen accumulating organisms ratio. Many authors have reported that the population of glycogen accumulating organisms (GAOs) increases with SRT (Satoh et al., 1994; Rodrigo et al., 1996; García-Usach, 2002). The temperature influence on BPR has also been investigated in numerous studies showing different results. While some authors have reported better phosphorus removal efficiencies at high temperatures $\left(20-37^{\circ} \mathrm{C}\right)$ (Mamais and Jenkins, 1992; Converti et al., 1995; Brdjanovic et al., 1997) others have reported better efficiencies at low temperatures $\left(5-15^{\circ} \mathrm{C}\right)$ (Barnard et al., 1985, Erdal et al., 2003). Moreover, the BPR requires the presence of volatile fatty acids (VFA), so the influence of different VFA composition on the BPR process has also been studied (Moser-Engeler et al., 1998; Schuler and Jenkins, 2003; Oehmen et al., 2004).

The study of biological nutrient removal processes involves a large number of interacting processes which require a deep analysis. Mathematical models have been found as very successful tools for research, development and optimization of biological nutrient removal processes since they include all the information related to the processes. Several models have been developed as the Activated Sludge Models proposed by the IWA (ASM1, ASM2, ASM2d, ASM3) or the TUDP model (Murnleitner et al., 1997). Among then, the ASM2d (Henze et al., 1999) is one of the most accepted for describing the behaviour of activated sludge processes for nutrient and organic matter (COD) removal.

The verification of a mathematical model provides an important tool for the investigation of advanced control strategies that may assist in the operation or control of WWTPs. Once the model has been calibrated, it can be used to optimize a non optimal performance, proposing modifications 
focused on the plant layout and the operation strategies, or to predict the plant performance when the influent conditions change (organic load increase, temperature variations, etc.).

The temperature influence on phosphorus accumulating organisms has been studied in this work using an organic matter and nutrient removal pilot plant. Two stationary-states, at different temperatures, have been calibrated and simulated using the ASM2d model. The Arrhenius equation constant has been obtained for phosphorous accumulating organisms (PAOs) processes. By means of the calibrated parameters and the Arrhenius relationship it has been simulated a third stationarystate at a new temperature.

\section{METHODS}

\section{Pilot plant}

The experiments were carried out in a pilot plant according to a variant of the modified UCT process. The pilot plant was located in a large WWTP of Valencia (Spain) and received $40 \mathrm{l} \mathrm{h}^{-1}$ of municipal raw wastewater. Major operation conditions and the layout of the pilot plant are shown in Figure 1. The pilot plant was operated at three different temperatures (13, 20 and $24.5^{\circ} \mathrm{C}$ ), reproducing the temperature variations of the region during the year. The sludge retention time was maintained in 10 days for all the experiments.

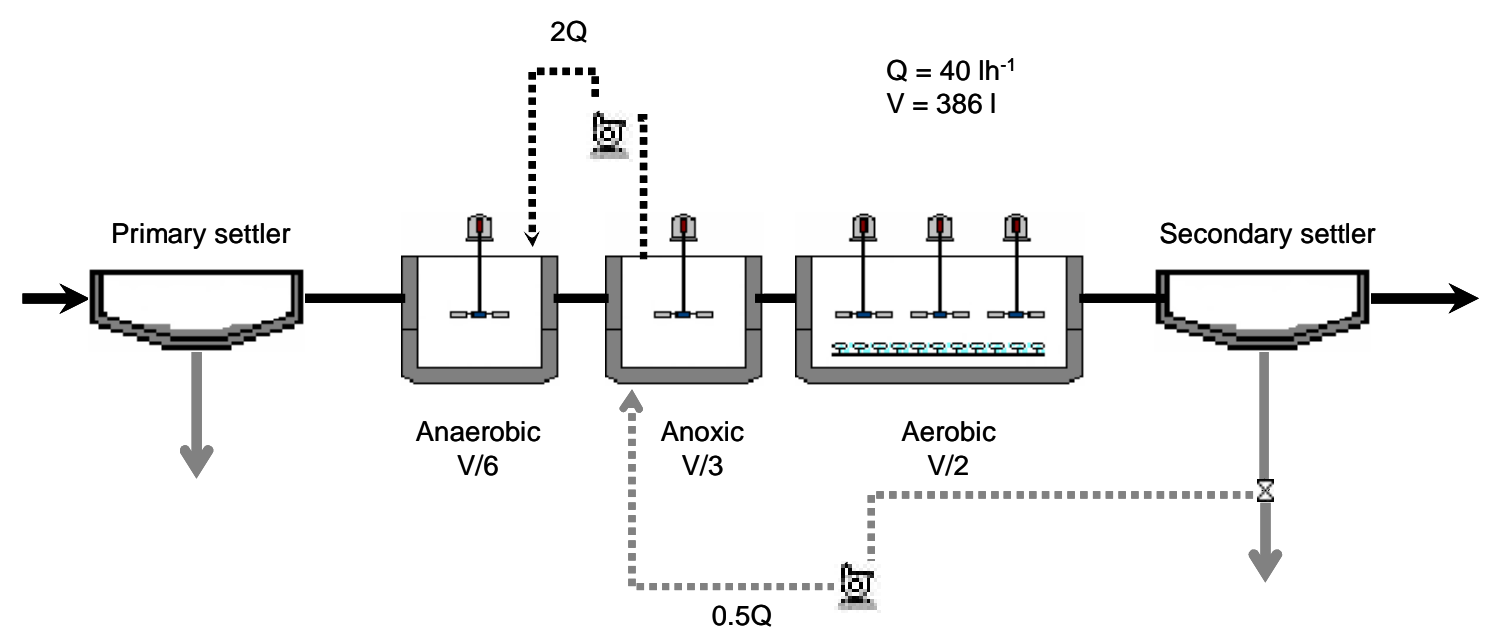

Figure 1 Pilot plant layout

\section{Measurements}

Application of the ASM2d model to full scale WWTPs requires experimental data on activated sludge and wastewater characteristics. Integrated samples were collected on a daily basis from influent, effluent and anaerobic, anoxic and aerobic reactors. The influent and effluent characterization consisted in analysing total suspended solids (TSS), volatile suspended solids (VSS), $\mathrm{COD}_{\text {total }}, \mathrm{COD}_{\text {filtered}}, \mathrm{BOD}_{1}$ total, $\mathrm{BOD}_{1}$ filtered, $\mathrm{VFA}, \mathrm{NO}_{3}-\mathrm{N}, \mathrm{NH}_{4}-\mathrm{N}$, total nitrogen $\left(\mathrm{N}_{\text {tot }}\right)$, total phosphorus $\left(\mathrm{P}_{\mathrm{tot}}\right), \mathrm{PO}_{4}-\mathrm{P}$ and alkalinity $(\mathrm{Alk})$. The average measurements results obtained in the three experiments are presented in Table 1. Mixed liquor suspended solids (MLSS), $\mathrm{COD}_{\text {total, }} \mathrm{NO}_{3}-$ $\mathrm{N}, \mathrm{NH}_{4}-\mathrm{N}$ and $\mathrm{PO}_{4}-\mathrm{P}$ were determined for activated sludge characterization.

Most of the analytical techniques used in this work were in accordance with Standard Methods (1998) (TSS, VSS, COD, $\left.\mathrm{NH}_{4}-\mathrm{N}, \mathrm{P}_{\text {tot }}, \mathrm{PO}_{4}-\mathrm{P}\right)$. COD (10-125 $\left.\mathrm{mg} \mathrm{l}^{-1}\right), \mathrm{NO}_{3}-\mathrm{N}$ and Total $\mathrm{N}$ were determined with specific MERK kits. VFA were determined by titration using the method proposed by WRC (1992). BOD was determined by pressure measurements using a WTW OXITOP CONTROL system. 
Table 1 Influent and effluent wastewater characteristics

\begin{tabular}{|c|c|c|c|c|c|c|c|}
\hline \multirow{2}{*}{ Parameter } & \multirow{2}{*}{ Unit } & \multicolumn{3}{|c|}{ Influent } & \multicolumn{3}{|c|}{ Effluent } \\
\hline & & $13^{\circ} \mathrm{C}$ & $20^{\circ} \mathrm{C}$ & $24.5^{\circ} \mathrm{C}$ & $13^{\circ} \mathrm{C}$ & $20^{\circ} \mathrm{C}$ & $24.5^{\circ} \mathrm{C}$ \\
\hline TSS & $\mathrm{mg} \mathrm{l}^{-1}$ & 76 & 57 & 50 & 7 & 6 & 7 \\
\hline VSS & $\mathrm{mg} \mathrm{l}^{-1}$ & 72 & 41 & 39 & 6 & 5 & 6 \\
\hline $\mathrm{COD}_{\text {total }}$ & $\mathrm{mgCOD} \mathrm{l}^{-1}$ & 286 & 265 & 222 & 36 & 23 & 33 \\
\hline $\mathrm{COD}_{\text {filtered }}$ & $\mathrm{mgCOD} \mathrm{l}^{-1}$ & 169 & 157 & 139 & 28 & 22 & 30 \\
\hline BODl total & $\mathrm{mgCOD} \mathrm{l}^{-1}$ & 213 & 216 & 190 & 10 & 13 & 15 \\
\hline BOD ${ }_{\text {l filtered }}$ & mgCOD $^{-1}$ & 145 & 150 & 119 & 4 & 7 & 10 \\
\hline VFA & $\mathrm{mgCOD}^{-1}$ & 78 & 83 & 81 & 0 & 0 & 0 \\
\hline $\mathrm{NO}_{3}-\mathrm{N}$ & $\mathrm{mgN} \mathrm{l}^{-1}$ & $<0.2$ & $<0.2$ & $<0.2$ & 1.7 & 12.7 & 11.2 \\
\hline $\mathrm{NH}_{4}-\mathrm{N}$ & $\mathrm{mgN} \mathrm{l}^{-1}$ & 26.3 & 26.2 & 17.6 & 16.8 & 0.5 & 0 \\
\hline $\mathrm{N}_{\text {tot }}$ & $\operatorname{mgN~l}^{-1}$ & 36.4 & 33.9 & 25.8 & 26.9 & 14.7 & 11.9 \\
\hline $\mathrm{N}_{\text {tot filtered }}$ & $\mathrm{mgN} \mathrm{l}^{-1}$ & 31.6 & 29.5 & 21.0 & 26.4 & 14.6 & 11.6 \\
\hline $\mathrm{P}_{\text {tot }}$ & $\mathrm{mgP} \mathrm{l}^{-1}$ & 8.9 & 8.7 & 8.7 & 0.5 & 2.1 & 1.4 \\
\hline $\mathrm{PO}_{4}-\mathrm{P}$ & $\mathrm{mgP} \mathrm{l}^{-1}$ & 7.4 & 6.8 & 6.8 & 0.3 & 0.3 & 0.7 \\
\hline Alk & $\mathrm{mgCaCO}_{3} \mathrm{l}^{-1}$ & 390 & 353 & 353 & 375 & 320 & 335 \\
\hline
\end{tabular}

The experimental results indicated that the phosphorous removal process was efficiently performed in the three experiments showing a maximum phosphorous removal percentage at $13^{\circ} \mathrm{C}(\approx 94 \%)$. The nitrification process was achieved at $20^{\circ} \mathrm{C}$ and $24.5^{\circ} \mathrm{C}$ as indicates the low ammonia concentration in the effluent flow. Nevertheless, the nitrification was minimal at $13^{\circ} \mathrm{C}$, as was expected at this low temperature value.

\section{RESULTS AND DISCUSSION}

Wastewater characterization

A previous step to the ASM2d calibration consists in determining the different wastewater organic components: inert soluble COD $\left(\mathrm{S}_{\mathrm{I}}\right)$, readily biodegradable $\mathrm{COD}\left(\mathrm{S}_{\mathrm{F}}\right)$, volatile fatty acids $\left(\mathrm{S}_{\mathrm{A}}\right)$, heterotrophic biomass $\left(\mathrm{X}_{\mathrm{H}}\right)$, nitrifying biomass $\left(\mathrm{X}_{\mathrm{AUT}}\right)$, phosphorus accumulating biomass (XPA), storage products of PAOs $\left(\mathrm{X}_{\mathrm{PHA}}\right)$, inert particulate $\left(\mathrm{X}_{\mathrm{I}}\right)$ and slowly biodegradable organic matter $\left(X_{S}\right)$. The wastewater characterization was carried out following a physico-chemical separation technique as described in Penya-Roja et al. (2002). The obtained results are summarised in Table 2.

Table 2 Wastewater characterization

\begin{tabular}{llccc}
\hline Parameter & Unit & $13^{\circ} \mathrm{C}$ & $20^{\circ} \mathrm{C}$ & $24.5^{\circ} \mathrm{C}$ \\
\hline $\mathrm{S}_{\mathrm{I}}$ & mgCOD l$^{-1}$ & 24 & 15 & 20 \\
$\mathrm{~S}_{\mathrm{F}}$ & mgCOD l $^{-1}$ & 67 & 59 & 38 \\
$\mathrm{~S}_{\mathrm{A}}$ & mgCOD l $^{-1}$ & 78 & 83 & 81 \\
$\mathrm{X}_{\mathrm{I}}$ & mgCOD l $^{-1}$ & 49 & 34 & 12 \\
$\mathrm{X}_{\mathrm{S}}$ & mgCOD l$^{-1}$ & 68 & 74 & 71 \\
$\mathrm{~S}_{\mathrm{NO} 3}$ & $\mathrm{mgN} \mathrm{l}^{-1}$ & 0 & 0 & 0 \\
$\mathrm{~S}_{\mathrm{NH} 4}$ & $\mathrm{mgN} \mathrm{l}^{-1}$ & 26.3 & 26.2 & 17.6 \\
$\mathrm{~S}_{\mathrm{PO} 4}$ & $\mathrm{mgP} \mathrm{l}^{-1}$ & 7.4 & 6.8 & 6.8 \\
\hline
\end{tabular}

\section{Calibration}

Given the high number of parameters included in the ASM2d, a selective calibration was done. High influence kinetic and stoichiometric parameters were determined using off-line calibration 
techniques according to Penya-roja et al. (2002). Off-line calibration comprises respirometric techniques and individualized analysis of the different processes carried out by heterotrophic, nitrifying and phosphorus accumulating microorganisms. The calibration was performed for the 13 and $20^{\circ} \mathrm{C}$ experiments once the stationary-state was reached (at least after three times the sludge retention time). Table 3 shows the kinetic and stoichiometric parameters obtained for heterotrophic, nitrifying and phosphorous accumulating organisms.

Table 3 Heterotrophic, nitrifying and PAO parameter values

\begin{tabular}{|c|c|c|c|c|}
\hline Parameter & Unit & $13^{\circ} \mathrm{C}$ & $20^{\circ} \mathrm{C}$ & $24.5^{\circ} \mathrm{C}$ \\
\hline$Y_{H}$ & $\mathrm{mgCOD} \mathrm{mgCOD}^{-1}$ & 0.54 & 0.58 & 0.58 \\
\hline$\mu_{\mathrm{H}}$ & $\mathrm{d}^{-1}$ & 1.22 & 1.38 & 2.66 \\
\hline $\mathrm{K}_{\mathrm{F}}$ & $\operatorname{mgCOD~} \mathrm{l}^{-1}$ & 8.69 & 0.84 & 8.69 \\
\hline $\mathrm{b}_{\mathrm{H}}$ & $\mathrm{d}^{-1}$ & 0.19 & 0.39 & 0.41 \\
\hline$\eta_{\mathrm{NO}}$ & & 0.56 & 0.26 & 0.56 \\
\hline$\mu_{\mathrm{A}}$ & $\mathrm{d}^{-1}$ & --- & 1.14 & 1.90 \\
\hline $\mathrm{K}_{\mathrm{NH} 4}$ & $\mathrm{mgN} \mathrm{l}^{-1}$ & --- & 0.23 & 0.23 \\
\hline $\mathrm{b}_{\mathrm{A}}$ & $\mathrm{d}^{-1}$ & --- & 0.20 & 0.33 \\
\hline $\mathrm{Y}_{\mathrm{PO} 4}$ & $\mathrm{mgP} \mathrm{mgCOD}^{-1}$ & 0.46 & 0.42 & 0.40 \\
\hline СРНА & $\mathrm{d}^{-1}$ & 3.14 & 4.00 & 4.67 \\
\hline $\mathrm{K}_{\mathrm{A}}$ & $\operatorname{mgCOD~}^{-1}$ & 1.00 & 1.00 & 1.00 \\
\hline $\mathrm{Y}_{\mathrm{PAO}}$ & $\mathrm{mgCOD} \mathrm{mgCOD}^{-1}$ & 0.67 & 0.65 & 0.64 \\
\hline$\mu_{\mathrm{PAO}}$ & $d^{-1}$ & 1.56 & 2.31 & 2.97 \\
\hline qPP & $\operatorname{mgP} \operatorname{mgCOD}^{-1} \mathrm{~d}^{-1}$ & 2.28 & 3.27 & 4.12 \\
\hline bРАO & $\mathrm{d}^{-1}$ & 0.12 & 0.20 & 0.27 \\
\hline $\mathrm{K}_{\mathrm{PHA}}$ & mgCOD mgCOD $^{-1}$ & 0.076 & 0.071 & 0.068 \\
\hline $\mathrm{K}_{\text {IPP }}$ & $\mathrm{mgP} \mathrm{mgCOD}^{-1}$ & 0.007 & 0.007 & 0.007 \\
\hline$K_{\text {MAX }}$ & $\mathrm{mgP} \mathrm{mgCOD}^{-1}$ & 0.34 & 0.34 & 0.34 \\
\hline$\eta_{\mathrm{NO}}$ & & 0.56 & 0.44 & 0.56 \\
\hline
\end{tabular}

The calibration procedure, as well as, the experimental values showed that no significant nitrification took place at $13^{\circ} \mathrm{C}$ and 10 days of sludge retention time.

The heterotrophic kinetic parameters obtained at $20^{\circ} \mathrm{C}$ indicated inhibition problems reflected in a low maximum growth rate and in a low reduction factor for denitrification. Nevertheless, the nitrifying and PAOs organisms were not affected by this inhibition. This fact can be explained considering that the inhibition was a consequence of leached liquor discharges, with a high content in heavy metals, received in the WWTP during this operational period. Heavy metals use to be combined with organic matter forming complex compounds which have greater effects on the heterotrophic organisms than on the nitrifying and PAOs organisms (Braam and Klapqijk, 1981; Kong et al., 1996).

The PAOs parameter values $\mathrm{Y}_{\mathrm{PO} 4}, \mathrm{Y}_{\mathrm{PAO}}$ and $\mathrm{K}_{\mathrm{MAX}}$ can be used to indicate the presence of GAOs (Penya-roja et al., 2002; Ferrer et al., 2004). As GAOs are not included in the ASM2d model, its presence can be detected in the PAOs parameters values. The values obtained for these parameters in the two stationary-states calibrated are quite similar to the ASM2d values, so it can be assumed the absence of GAOs in the process.

As it has been said before, the $24.5^{\circ} \mathrm{C}$ stationary-state was not calibrated. The ASM2d parameters, needed for the simulation, were calculated using the Arrhenius relationship (Eq. 1). The use of this 
equation requires a set of calibrated parameters and the values of the Arrhenius constant for each model parameter. In the case of PAOs, the $a$ constant values of the Arrhenius equation were calculated using the ASM2d calibrated parameters obtained at $13^{\circ} \mathrm{C}$ and $20^{\circ} \mathrm{C}$ experiments (Table 4). Afterwards, the $24.5^{\circ} \mathrm{C}$ model parameters for PAOs were determined using the obtained constants and the calibrated parameters at $20^{\circ} \mathrm{C}$. However, due to the presence of inhibitory effects at $20^{\circ} \mathrm{C}$ for the heterotrophic organisms and the absence of nitrification at $13^{\circ} \mathrm{C}$, the use of ASM2d Arrhenius constants was required. The heterotrophic parameters at $24.5^{\circ} \mathrm{C}$ were calculated using the $13^{\circ} \mathrm{C}$ calibrated values and the ASM2d Arrhenius constant (1.07). In that way, the nitrifying parameters at $24.5^{\circ} \mathrm{C}$ were calculated using the $20^{\circ} \mathrm{C}$ calibrated values and the respective ASM2d Arrhenius constant (1.12).

$\mathrm{k} 1=\mathrm{k} 2 * \mathrm{a}^{(\mathrm{T} 1-\mathrm{T} 2)}$

Table 4 Arrhenius constant value for PAOs model parameters

\begin{tabular}{|c|c|c|c|}
\hline Parameter & $\mathrm{a}$ & & \\
\hline $\mathrm{Y}_{\mathrm{PO} 4}$ & 0.987 & qPP & 1.053 \\
\hline १РНА & 1.035 & bPAO & 1.071 \\
\hline $\mathrm{K}_{\mathrm{A}}$ & 1.000 & $\mathrm{~K}_{\mathrm{PHA}}$ & 0.990 \\
\hline $\mathrm{Y}_{\mathrm{PAO}}$ & 0.996 & $\mathrm{~K}_{\mathrm{IPP}}$ & 1.000 \\
\hline$\mu_{\mathrm{PAO}}$ & 1.058 & $\mathrm{~K}_{\mathrm{MAX}}$ & 1.000 \\
\hline
\end{tabular}

Attending to the Arrhenius constant values summarised in Table 4, the PAOs model parameters can be classified into two groups: on the one hand the non temperature dependent parameters $(\mathrm{a} \approx 1)$ where the saturation, the inhibition and the stoichiometric coefficients, excepting $\mathrm{Y}_{\mathrm{PO} 4}$ are included; and on the other hand the temperature dependent parameters $(a \neq 1)$ where the kinetic parameters qPHA, qPP, $\mu_{\mathrm{PAO}}$ and bPAO $_{\mathrm{Pre}}$ included.

In the ASM2d, the PAOs processes, excepting the lysis process, are considered to have the same temperature dependency value $(\mathrm{a}=1.041)$. The mean value of the Arrhenius constant obtained for

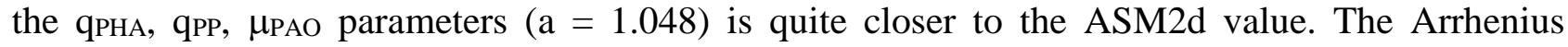
constant value obtained for the bPAo parameter $(\mathrm{a}=1.071)$ agrees with the ASM2d value.

Unlike ASM2d, many authors use to set different Arrhenius constant values depending on the PAOs process considered. The reason for that is based on the idea that the temperature affects the biological phosphorus removal sub-processes in a different way. The experimental and the literature Arrhenius constant values found for each process carried out by PAOs are summarised in Table 5.

In anaerobic conditions, the $a$ values obtained for the rate constant for storage of polyhydroxialkanoates ( ( $\mathrm{PHA}$ ) and the maximum rate for phosphorous release (estimated as the product $\left.\mathrm{Y}_{\mathrm{PO} 4} \cdot \mathrm{q}_{\mathrm{PHA}}\right)$ were 1.035 and 1.022 respectively. As it can be observed, the temperature influence on the maximum rate for polyhydroxialkanoates storage is greater than the influence on the maximum rate for phosphorous release. This tendency, showed in the PAOs anaerobic processes, agrees with the literature data showed in Table 5.

In aerobic conditions, the $a$ values obtained for the rate constant for storage of polyphosphate (qpP) and for the maximum growth rate ( $\left.\mu_{\mathrm{PAO}}\right)$ were 1.053 and 1.058 respectively. These values are closer to those proposed by Mamais and Jenkins (1992) but differ considerably from those obtained by Brdjanovic et al. (1998). The experimental conditions used by Mamais and Jenkins (1992) were very similar to those used in this work, where the activated sludge was acclimatized to the studied 
temperature and the sludge retention time was kept constant and low enough to avoid the GAOs presence. On the contrary, Brdjanovic et al. (1998) used a different methodology where not only the temperature was changed during the study but also the sludge retention time.

Table 5 Literature Arrhenius constant values for PAOs processes

\begin{tabular}{lcccc}
\hline Author & PHA Storage & P release & PP Storage & Growth \\
\hline Experimental values & 1.035 & 1.022 & 1.053 & 1.058 \\
Mamais and Jenkins (1992) & 1.048 & 1.043 & 1.055 & 1.053 \\
ASM2d (1999) & 1.041 & 1.041 & 1.041 & 1.041 \\
Brdjanovic et al. (1997) & $1.080 \pm 0.011$ & $1.055 \pm 0.019$ & $1.048 \pm 0.012$ & - \\
Brdjanovic et al. (1998) & $1.095 \pm 0.013$ & $1.075 \pm 0.012$ & $1.031 \pm 0.017$ & $>1.110$ \\
Helmer and Kunst (1998) & - & 1.018 & 1.025 & - \\
Baetens et al. (1999) & $1.079 \pm 0.024$ & $1.071 \pm 0.032$ & $1.067 \pm 0.006$ & - \\
\hline
\end{tabular}

\section{Simulation}

Once the kinetic and stoichiometric parameters were determined, the plant behaviour was simulated in order to reproduce the experimental data obtained at the three studied temperatures. The simulation task was performed using the software DESASS (DEsign and Simulation of Activated Sludge Systems) (Seco et al., 2004). The simulation results for the two experiments calibrated $\left(13^{\circ} \mathrm{C}\right.$ and $\left.20^{\circ} \mathrm{C}\right)$ are summarised in Table 6 and Table 7 showing a good correspondence with the experimental data.

The $24.5^{\circ} \mathrm{C}$ experiment simulation was carried out using the model parameters obtained by means of the Arrhenius equation. The simulated results also showed a good correspondence with the experimental data (Table 8).

Table 6 Experimental and simulated values at $13^{\circ} \mathrm{C}$

\begin{tabular}{|c|c|c|c|c|c|c|c|c|c|}
\hline \multirow{2}{*}{ Parameter } & \multirow{2}{*}{ Unit } & \multicolumn{2}{|c|}{ Anaerobic } & \multicolumn{2}{|c|}{ Anoxic } & \multicolumn{2}{|c|}{ Aerobic } & \multicolumn{2}{|c|}{ Effluent } \\
\hline & & Exp & Sim & Exp & Sim & Exp & Sim & Exp & Sim \\
\hline TSS & $\mathrm{mg} \mathrm{l}^{-1}$ & 2356 & 2428 & 3271 & 3232 & 3376 & 3327 & 7 & 7 \\
\hline $\mathrm{COD}_{\text {total }}$ & $\mathrm{mgCOD}^{-1}$ & 3050 & 2798 & 3886 & 3875 & 3829 & 3798 & 36 & 40 \\
\hline $\mathrm{NO}_{3}-\mathrm{N}$ & $\mathrm{mgN} \mathrm{l}^{-1}$ & $<0.2$ & 0.0 & $<0.2$ & 0.0 & 0.8 & 1.0 & 1.7 & 1.0 \\
\hline $\mathrm{NH}_{4}-\mathrm{N}$ & $\mathrm{mgN} \mathrm{l}^{-1}$ & 23.4 & 25.9 & 23.2 & 25.5 & 21.0 & 19.6 & 16.8 & 20.0 \\
\hline $\mathrm{PO}_{4}-\mathrm{P}$ & $\mathrm{mgP} \mathrm{l}^{-1}$ & 33.6 & 34.5 & 33.7 & 33.6 & 0.4 & 1.0 & 0.3 & 1.1 \\
\hline
\end{tabular}

Table 7 Experimental and simulated values at $20^{\circ} \mathrm{C}$

\begin{tabular}{|c|c|c|c|c|c|c|c|c|c|}
\hline \multirow{2}{*}{ Parameter } & \multirow{2}{*}{ Unit } & \multicolumn{2}{|c|}{ Anaerobic } & \multicolumn{2}{|c|}{ Anoxic } & \multicolumn{2}{|c|}{ Aerobic } & \multicolumn{2}{|c|}{ Effluent } \\
\hline & & Exp & Sim & Exp & Sim & Exp & Sim & Exp & Sim \\
\hline TSS & $\mathrm{mg} \mathrm{l}^{-1}$ & 1701 & 1779 & 2546 & 2568 & 2704 & 2658 & 6 & 7 \\
\hline $\mathrm{COD}_{\text {total }}$ & $\mathrm{mgCOD} \mathrm{l}^{-1}$ & 2170 & 2121 & 2978 & 2946 & 2762 & 2860 & 23 & 24 \\
\hline $\mathrm{NO}_{3}-\mathrm{N}$ & $\mathrm{mgN} \mathrm{l}^{-1}$ & 0.7 & 0.0 & $<0.2$ & 0.2 & 16.9 & 17.6 & 12.7 & 15.5 \\
\hline $\mathrm{NH}_{4}-\mathrm{N}$ & $\mathrm{mgN} \mathrm{l}^{-1}$ & 18.9 & 21.1 & 18.1 & 18.7 & 0.6 & 0.5 & 0.5 & 0.5 \\
\hline $\mathrm{PO}_{4}-\mathrm{P}$ & $\mathrm{mgP} \mathrm{l}^{-1}$ & 28.6 & 29.9 & 26.4 & 28.8 & 0.6 & 1.0 & 0.3 & 0.7 \\
\hline
\end{tabular}


Table 8 Experimental and simulated values at $24.5^{\circ} \mathrm{C}$

\begin{tabular}{|c|c|c|c|c|c|c|c|c|c|}
\hline \multirow{2}{*}{ Parameter } & \multirow{2}{*}{ Unit } & \multicolumn{2}{|c|}{ Anaerobic } & \multicolumn{2}{|c|}{ Anoxic } & \multicolumn{2}{|c|}{ Aerobic } & \multicolumn{2}{|c|}{ Effluent } \\
\hline & & Exp & Sim & Exp & Sim & Exp & Sim & Exp & Sim \\
\hline TSS & $\mathrm{mg} \mathrm{l}^{-1}$ & 1418 & 1360 & 1988 & 1961 & 2057 & 2027 & 7 & 7 \\
\hline $\mathrm{COD}_{\text {total }}$ & $\mathrm{mgCOD} \mathrm{l}^{-1}$ & 1502 & 1506 & 2088 & 2079 & 2073 & 2009 & 33 & 32 \\
\hline $\mathrm{NO}_{3}-\mathrm{N}$ & $\mathrm{mgN} \mathrm{l}^{-1}$ & 0.8 & 0.0 & 0.7 & 0.1 & 11.2 & 11.3 & 11.2 & 11.0 \\
\hline $\mathrm{NH}_{4}-\mathrm{N}$ & $\mathrm{mgN}^{-1}$ & 14.0 & 14.0 & 10.2 & 12.3 & 0.0 & 0.3 & 0.0 & 0.3 \\
\hline $\mathrm{PO}_{4}-\mathrm{P}$ & $\mathrm{mgP}^{-1}$ & 26.0 & 26.1 & 22.4 & 25.2 & 1.0 & 1.0 & 0.7 & 0.9 \\
\hline
\end{tabular}

\section{CONCLUSIONS}

The phosphorous removal process was efficiently performed in the three experiments carried out showing a maximum value at $13^{\circ} \mathrm{C}$. The PAOs calibrated parameters indicated the absence of GAOs in the process.

The Arrhenius constant values obtained for the PAOs reflected that the temperature influences on the biological phosphorus removal sub-processes in a different way. The maximum rate for polyhydroxialkanoates storage is more influenced by the temperature than the maximum rate for phosphorous release.

No calibration step was necessary for the $24.5^{\circ} \mathrm{C}$ experiment. The model parameters for this temperature were calculated by means of the Arrhenius equation and the calibrated parameters at $13^{\circ} \mathrm{C}$ and $20^{\circ} \mathrm{C}$. The simulation results accurately reproduced the experimental data.

On balance, the good simulation results point out the advantage of using calibrated models and simulation tools in order to predict changes in wastewater process performance.

\section{ACKNOWLEDGEMENT}

The authors express their acknowledgements to the Entitat Pública de Sanejament d'Aigües Residuals de la Comunitat Valenciana, SEARSA and AQUAGEST for their financial support.

\section{REFERENCES}

Baetens D., Vanrolleghem P. A, van Loosdrecht M. C. M. and Hosten L. H. (1999). Temperature effects in Bio-P removal. Wat. Sci. Tech., 39(1), 215-225.

Barnard J. L., Stevens G. M and Leslie P. J. (1985). Design strategies for nutrient removal plant. Wat. Sci. Tech., 17(11/12), 233-242.

Braam F. and Klapwijk A. (1981). Effect of copper on nitrification in activated sludge. Wat. Res. 15, 1093-1098.

Brdjanovic D., van Loosdrecht M. C. M., Hooijmans C. M., Alaerts G. J. and Heijnen J. J. (1997). Temperature effects on physiology of biological phosphorus removal. Journal of Environmental Engineering. 144-153.

Brdjanovic D., van Loosdrecht M. C. M., Hooijmans C. M., Alaerts G. J. and Heijnen J. J. (1998). Influence of temperature on biological phosphorus removal: process and molecular ecological studies. Wat. Res., 32(4) 10351048.

Converti A., Rovatti M. and Borghi, M (1995). Biological removal of phosphorus form wastewaters by alternating aerobic and anaerobic conditions. Wat. Res., 29, 263-267.

Erdal U.G., Erdal Z.K., Randall, C. W. (2003). The competition between PAOs (phosphorus accumulating organisms) and GAOs (glycogen accumulating organisms) in EBPR (enhanced biological phosphorus removal) systems at different temperatures and the effects on system performance. Wat. Sci. Tech., 47 (11), 1-8.

Ferrer J., Morenilla J.J., Bouzas A. and Garcia-Usach F. (2004). Calibration and simulation of two large wastewater treatment plants operated for nutrient removal. Wat. Sci. Tech., 50(6), 87-94. 
García-Usach F. (2002). Influence of sludge retention time and temperature on biological matter and nutrient removal of wastewaters. PhD thesis, Department of Hydraulic Engineering and Environment, Universidad Politécnica de Valencia.

Helmer C. and Kunst S. (1998). Low temperature effects on phosphorus release and uptake by microorganisms in EBPR plants. Wat. Sci. Tech., 37(4-5), 531-539.

Henze M., Gujer W., Mino T., Matsuo, Wentzel M.C., Marais G.v.R. and Van Loosdrecht M.C.M. (1999). Activated Sludge Model No. 2d. Wat. Sci. Tech., 39(1), 165-182.

Kong Z., Vanrolleghem P., Willems P. and Verstraete W. (1996). Simultaneous determination of inhibition kinetics of carbon oxidation and nitrification with a respirometer. Wat. Res. 30, 825-836.

Mamais D. and Jenkins D. (1992). The effects of MCRT and temperature on enhanced biological phosphorus removal. Wat. Sci. Tech., 26 (5/6), 955-965.

Moser-Engeler R., Udert K.M., Wild D. and Siegrist H. (1998). Products from primary sludge fermentation and their suitability for nutrient removal. Wat. Sci. Tech. 38, 265-273.

Murnleitner E., Kuba T., van Loosdrecht M. C. M. and Heijnen J. J. (1997). An integrated model for the aerobic and denitrifying biological phosphorus process. Biotechnol. Bioeng., 54, 434-450.

Oehmen A., Yuan Z., Blackall L. and Keller J. (2004). Short-term effects of carbon source on the competition of polyphosphate accumulating organisms and glycogen accumulating organisms. Proceedings of 3rd IWA Specialised Conference on sequencing Batch Reactor Technology (SBR3). Noosa, Queensland, Australia.

Penya-Roja J.M., Seco A., Ferrer J., Serralta J. (2002). Calibration and validation of Activated Sludge Model No. 2d for Spanish municipal wastewater. Environ. Technol., 23, 849-862.

Rodrigo M. A., Seco A., Ferrer J. and Penya-Roja, J. M. (1996). Influence of sludge age on enhanced phosphorus removal in biological systems. Wat. Sci. Tech., 34 (1/2), 41-48.

Satoh H., Mino T. and Matsuo, T. (1994). Deterioration of enhanced biological phosphorus removal by the domination of microorganisms without polyphosphate accumulation. Wat. Sci. Tech., 30, 203-211.

Schuler A.J. and Jenkins D. (2003). Enhanced biological phosphorus removal from wastewater by biomass with different phosphorus contents, Part I: Experimental results and comparison with methabolic models. Water Environment Research 75(6), 485-498.

Seco A., Ribes J., Serralta J. and Ferrer J. Biological nutrient removal model No.1 (BNRM1) (2004). Wat. Sci. Tech., 50(6), 69-78.

Standard Methods for the Examination of Water and Wastewater (1998). 20 ${ }^{\text {th }}$ edn, American Public Health Association, American Water Works Association and Water Environment Federation , Washington DC, USA.

Water Research Commission (1992). Simple titration procedures to determine $\mathrm{H}_{2} \mathrm{CO}_{3}{ }^{*}$ alkalinity and short-chain fatty acids in aqueous solutions containing known concentrations of ammonium, phosphate and sulphide weak acid/bases, Report No. TT 57/92, Water Research Commission, University of Cape Town, Pretoria, Republic of South Africa. 